\title{
SEROTYPE, MATING TYPE AND PLOIDY OF Cryptococcus neoformans STRAINS ISOLATED FROM PATIENTS IN BRAZIL
}

\author{
Misako OHKUSU(1), Naomi TANGONAN(1), Kanji TAKEO(1), Eriko KISHIDA(1), Masami OHKUBO(1), Shigeji AOKI(2), Kenjiro NAKAMURA(2), Takaaki FUJII(3), \\ Isadora C. de SIQUEIRA(4), Elves A.P. MACIEL(4), Sumire SAKABE(4), Gisele M.D. ALMEIDA(4), Elisabeth M. HEINS-VACCARI(5) \& Carlos da S. LACAZ(5)
}

\begin{abstract}
SUMMARY
Serotype, mating type and ploidy of 84 strains of Cryptococcus neoformans isolated from 61 AIDS and 23 non-AIDS patients admitted in a tertiary teaching hospital in São Paulo, Brazil were examined. Among 61 strains isolated from AIDS patients, 60 strains were var. grubii (serotype A). Only one strain was var. gattii (serotype B). No var. neoformans (serotype D) was found. Among 23 strains isolated from non-AIDS patients, 15 were var. grubii (serotype A) and the remaining 8 were var. gattii, all of which were serotype B. Seventy-three of the 75 serotype A strains were the heterothallic $\alpha$ type (MAT $\alpha)$ and the remaining 2 were untypable (asexual). Most of the MAT $\alpha$ strains (69/73) were haploid and the remaining 4 strains were diploid. Similarly, both of the 2 asexual strains among the 75 serotype A strains were haploid. There were no $\alpha$-mating type (MATa) strains among the 84 isolates. All of the 8 var. gattii strains were serotype B and haploid. Among a total of 84 strains tested, neither serotype AD nor serotype D were found. Neither triploid nor tetraploid were found. These results suggest that the serological, sexual and ploidy characteristics in $C$. neoformans strains isolated from AIDS patients in São Paulo were rather simple, whereas strains isolated from non-AIDS patients presented serotype A and B with predominance of serotype A.
\end{abstract}

KEYWORDS: AIDS; Cryptococcus neoformans; Mating type; Ploidy; Serotype

\section{INTRODUCTION}

Cryptococcus neoformans, the anamorph of Filobasidiella neoformans, exists worldwide in nature, such as in pigeon droppings and Eucalyptus trees ${ }^{3,17}$. It causes the most serious deep-seated mycoses among the basidiomycetous fungi, and is one of the most life-threatening pathogens in AIDS patients ${ }^{3}$. Two mating loci with four different mating alleles are common among basidiomycetous fungi. C. neoformans, however, has only one mating locus with two mating type, i.e., alpha (MAT $\alpha)$ and $a(\mathrm{MAT} a)$. The $\alpha$-mating type strains have been shown to be more virulent than the $\alpha$-mating types ${ }^{12}$. C. neoformans has five serotypes (A, B, C, D and AD), and is subdivided into the three varieties, i.e. var grubii (serotype A), var. neoformans (serotypes D) and var. gattii (serotypes B and C) ${ }^{6}$. PCR analysis with primers specific for genes in the MAT $a$ or MAT $\alpha$ mating-type loci revealed that serotype AD strains are heterozygous for the mating locus. Serotype AD strains of $C$. neoformans are unusual aneuploid or diploid strains that result from matings between serotype A and D strains ${ }^{16}$. Var. grubii is geographically distributed throughout the world, while var. gattii is most frequently found in tropical and subtropical regions ${ }^{17}$. Var. neoformans is isolated rather frequently in Europe and South America ${ }^{17}$. Thus, it is of interest to determine the varieties and serotypes of $C$. neoformans isolates from patients in Brazil where all the varieties are endemic ${ }^{2,14,15,18,20,21,22}$.
Mating type and ploidy are also important for understanding the ecology and virulence of this fungus ${ }^{1,12}$. The serotype and mating type of clinical and environmental isolates of C. neoformans have been studied rather well, but only a few studies on ploidy have been performed with a large number of environmental and clinical isolates ${ }^{8,24}$. In the present study we report on the serotype, the mating type as well as ploidy of 84 C. neoformans strains isolated from AIDS and other patients living in São Paulo and surrounding areas.

\section{MATERIAL AND METHODS}

Test organisms: Eighty-four C. neoformans strains were isolated from patients with cryptococcosis who were hospitalized from 1996 to 2000 in Hospital das Clínicas (a 2200 bed tertiary care teaching Hospital, School of Medicine, University of São Paulo - SP, Brazil) were included in the study. These are listed in Tables 1 and 2, together with strain designations and with IFM (Research Center for Pathogenic Fungi and Microbial Toxicoses, Chiba University) number.

The majority of the isolates were from cerebral spinal fluid and blood respectively. The strains were identified by colonial morphology (demonstration of capsule, spherical shape, growth at $37^{\circ} \mathrm{C}$ ), conventional biochemichal test ${ }^{5}$ and/or using YBC Card Vitek System (Bio Mérieux, 


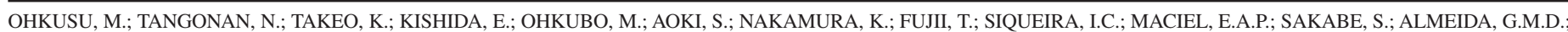
HEINS-VACCARI, E.M. \& LACAZ, C.S. - Serotype, mating type and ploidy of Cryptococcus neoformans strains isolated from patients in Brazil. Rev. Inst. Med. trop. S. Paulo, 44(6): 299-302, 2002.

Table 1

Ploidy, serotype and mating type of $C$. neoformans isolated from AIDS patients

\begin{tabular}{cccccc}
\hline Strain & IFM No.* & Serotype & Mating type & DNA content & Ploidy \\
\hline 48 & 51611 & $\mathrm{~A}$ & $\alpha$ & 1.00 & $\mathrm{H}$ \\
54 & 51612 & $\mathrm{~A}$ & $\alpha$ & 1.18 & $\mathrm{H}$ \\
55 & 51613 & $\mathrm{~A}$ & $\alpha$ & 0.94 & $\mathrm{H}$ \\
56 & 51614 & $\mathrm{~A}$ & $\alpha$ & 0.98 & $\mathrm{H}$ \\
57 & 51615 & $\mathrm{~A}$ & $\alpha$ & 1.02 & $\mathrm{H}$ \\
58 & 51616 & $\mathrm{~A}$ & $\alpha$ & 1.02 & $\mathrm{H}$ \\
65 & 51617 & $\mathrm{~A}$ & $\alpha$ & 0.86 & $\mathrm{H}$ \\
124 & 51618 & $\mathrm{~A}$ & $\alpha$ & 1.00 & $\mathrm{H}$ \\
181 & 51619 & $\mathrm{~A}$ & $\alpha$ & 1.00 & $\mathrm{H}$ \\
204 & 51620 & $\mathrm{~A}$ & $\alpha$ & 0.98 & $\mathrm{H}$ \\
228 & 51621 & $\mathrm{~A}$ & $\alpha$ & 0.90 & $\mathrm{H}$ \\
253 & 51623 & $\mathrm{~A}$ & $\alpha$ & 1.00 & $\mathrm{H}$ \\
298 & 51624 & $\mathrm{~A}$ & $\alpha$ & 0.98 & $\mathrm{H}$ \\
305 & 51622 & $\mathrm{~A}$ & $\alpha$ & 0.94 & $\mathrm{H}$ \\
349 & 51625 & $\mathrm{~A}$ & $\alpha$ & 0.98 & $\mathrm{H}$ \\
350 & 51626 & $\mathrm{~A}$ & $\alpha$ & 0.90 & $\mathrm{H}$ \\
352 & 51627 & $\mathrm{~A}$ & $\alpha$ & 1.20 & $\mathrm{H}$ \\
367 & 51628 & $\mathrm{~A}$ & $\alpha$ & 0.92 & $\mathrm{H}$ \\
369 & 51630 & $\mathrm{~A}$ & $\alpha$ & 0.92 & $\mathrm{H}$ \\
370 & 51631 & $\mathrm{~A}$ & $\alpha$ & 1.00 & $\mathrm{H}$ \\
387 & 51632 & $\mathrm{~A}$ & $\alpha$ & 0.94 & $\mathrm{H}$ \\
403 & 51634 & $\mathrm{~A}$ & $\alpha$ & 0.84 & $\mathrm{H}$ \\
410 & 51635 & $\mathrm{~A}$ & $\alpha$ & 0.82 & $\mathrm{H}$ \\
412 & 51636 & $\mathrm{~A}$ & $\alpha$ & 0.80 & $\mathrm{H}$ \\
416 & 51641 & $\mathrm{~A}$ & $\alpha$ & 0.84 & $\mathrm{H}$ \\
419 & 51637 & $\mathrm{~B}$ & $\mathrm{UT}$ & $\mathrm{H}$ & $\mathrm{H}$ \\
423 & 51638 & $\mathrm{~A}$ & $\alpha$ & 0.88 & $\mathrm{H}$ \\
426 & 51639 & $\mathrm{~A}$ & $\alpha$ & 0.98 & $\mathrm{H}$ \\
446 & 51642 & $\mathrm{~A}$ & $\alpha$ & 1.98 & $\mathrm{D}$ \\
462 & 51643 & $\mathrm{~A}$ & $\alpha$ & 2.14 & $\mathrm{D}$ \\
549 & 51650 & $\mathrm{~A}$ & $\mathrm{UT}$ & $\mathrm{H}$ & $\mathrm{H}$ \\
\hline & & & 1.12 & $\mathrm{H}$ \\
\hline
\end{tabular}

\begin{tabular}{cccccc}
\hline Strain & IFM No.* & Serotype & Mating type & DNA content & Ploidy \\
\hline 582 & 51652 & $\mathrm{~A}$ & $\mathrm{UT}^{\mathrm{a}}$ & 1.02 & $\mathrm{H}$ \\
695 & 51655 & $\mathrm{~A}$ & $\alpha$ & 1.00 & $\mathrm{H}$ \\
708 & 51657 & $\mathrm{~A}$ & $\alpha$ & 1.76 & $\mathrm{D}$ \\
742 & 51661 & $\mathrm{~A}$ & $\alpha$ & 0.84 & $\mathrm{H}$ \\
754 & 51662 & $\mathrm{~A}$ & $\alpha$ & 0.88 & $\mathrm{H}$ \\
772 & 51663 & $\mathrm{~A}$ & $\alpha$ & 0.80 & $\mathrm{H}$ \\
791 & 51664 & $\mathrm{~A}$ & $\alpha$ & 0.98 & $\mathrm{H}$ \\
795 & 51653 & $\mathrm{~A}$ & $\alpha$ & 0.86 & $\mathrm{H}$ \\
807 & 51666 & $\mathrm{~A}$ & $\alpha$ & 1.06 & $\mathrm{H}$ \\
808 & 51667 & $\mathrm{~A}$ & $\alpha$ & 1.00 & $\mathrm{H}$ \\
838 & 51668 & $\mathrm{~A}$ & $\alpha$ & 0.84 & $\mathrm{H}$ \\
853 & 51670 & $\mathrm{~A}$ & $\alpha$ & 0.96 & $\mathrm{H}$ \\
861 & 51671 & $\mathrm{~A}$ & $\alpha$ & 0.94 & $\mathrm{H}$ \\
863 & 51672 & $\mathrm{~A}$ & $\alpha$ & 0.82 & $\mathrm{H}$ \\
884 & 51674 & $\mathrm{~A}$ & $\alpha$ & 0.98 & $\mathrm{H}$ \\
890 & 51675 & $\mathrm{~A}$ & $\alpha$ & 0.92 & $\mathrm{H}$ \\
909 & 51677 & $\mathrm{~A}$ & $\alpha$ & 1.10 & $\mathrm{H}$ \\
917 & 51678 & $\mathrm{~A}$ & $\alpha$ & 1.20 & $\mathrm{H}$ \\
926 & 51680 & $\mathrm{~A}$ & $\alpha$ & 0.82 & $\mathrm{H}$ \\
946 & 51682 & $\mathrm{~A}$ & $\alpha$ & 1.00 & $\mathrm{H}$ \\
957 & 51685 & $\mathrm{~A}$ & $\alpha$ & 0.90 & $\mathrm{H}$ \\
961 & 51684 & $\mathrm{~A}$ & $\alpha$ & 0.90 & $\mathrm{H}$ \\
980 & 51694 & $\mathrm{~A}$ & $\alpha$ & 0.88 & $\mathrm{H}$ \\
981 & 51683 & $\mathrm{~A}$ & $\alpha$ & 0.86 & $\mathrm{H}$ \\
982 & 51686 & $\mathrm{~A}$ & $\alpha$ & 0.86 & $\mathrm{H}$ \\
1014 & 51687 & $\mathrm{~A}$ & $\alpha$ & 1.08 & $\mathrm{H}$ \\
1028 & 51689 & $\mathrm{~A}$ & $\alpha$ & 1.96 & $\mathrm{D}$ \\
1039 & 51690 & $\mathrm{~A}$ & $\alpha$ & 1.00 & $\mathrm{H}$ \\
1049 & 51691 & $\mathrm{~A}$ & $\alpha$ & 0.86 & $\mathrm{H}$ \\
$\mathrm{J} . \mathrm{C}$ & 51692 & $\mathrm{~A}$ & $\alpha$ & 1.00 & $\mathrm{H}$ \\
& & & & & \\
\hline
\end{tabular}

* Strain number of the Research Center for Pathogenic Fungi and Microbial Toxicoses, Chiba University; a = Untypable mating type.

Table 2

Ploidy, serotype and mating type of C. neoformans isolated from patients other than AIDS

\begin{tabular}{cccccc}
\hline Strain & IFM No. & Serotype & Mating type & DNA content & Ploidy \\
\hline 368 & 51629 & $\mathrm{~B}$ & $\mathrm{UT}$ & 0.88 & $\mathrm{H}$ \\
393 & 51633 & $\mathrm{~A}$ & $\alpha$ & 0.90 & $\mathrm{H}$ \\
439 & 51640 & $\mathrm{~A}$ & $\alpha$ & 1.12 & $\mathrm{H}$ \\
477 & 51644 & $\mathrm{~A}$ & $\alpha$ & 0.90 & $\mathrm{H}$ \\
484 & 51645 & $\mathrm{~B}$ & $\mathrm{UT}^{\mathrm{a}}$ & 0.98 & $\mathrm{H}$ \\
489 & 51647 & $\mathrm{~A}$ & $\alpha$ & 0.84 & $\mathrm{H}$ \\
491 & 51648 & $\mathrm{~A}$ & $\alpha$ & 0.92 & $\mathrm{H}$ \\
509 & 51649 & $\mathrm{~A}$ & $\alpha$ & 1.04 & $\mathrm{H}$ \\
571 & 51651 & $\mathrm{~B}$ & $\mathrm{UT}^{\mathrm{a}}$ & 1.02 & $\mathrm{H}$ \\
643 & 51654 & $\mathrm{~B}$ & $\mathrm{UT}^{\mathrm{a}}$ & 1.06 & $\mathrm{H}$ \\
694 & 51646 & $\mathrm{~A}$ & $\alpha$ & 0.96 & $\mathrm{H}$ \\
696 & 51656 & $\mathrm{~A}$ & $\alpha$ & 0.84 & $\mathrm{H}$
\end{tabular}

\begin{tabular}{cccccc}
\hline Strain & IFM No.* & Serotype & Mating type & DNA content & Ploidy \\
\hline 734 & 51658 & $\mathrm{~A}$ & $\alpha$ & 1.10 & $\mathrm{H}$ \\
738 & 51659 & $\mathrm{~A}$ & $\alpha$ & 0.84 & $\mathrm{H}$ \\
741 & 51660 & $\mathrm{~B}$ & $\mathrm{UT}^{\mathrm{a}}$ & 0.86 & $\mathrm{H}$ \\
801 & 51665 & $\mathrm{~A}$ & $\alpha$ & 0.82 & $\mathrm{H}$ \\
854 & 51669 & $\mathrm{~A}$ & $\alpha$ & 1.02 & $\mathrm{H}$ \\
878 & 51673 & $\mathrm{~A}$ & $\alpha$ & 0.88 & $\mathrm{H}$ \\
891 & 51676 & $\mathrm{~B}$ & $\mathrm{UT}^{\mathrm{a}}$ & 0.92 & $\mathrm{H}$ \\
918 & 51679 & $\mathrm{~A}$ & $\alpha$ & 0.90 & $\mathrm{H}$ \\
927 & 51681 & $\mathrm{~A}$ & $\alpha$ & 0.94 & $\mathrm{H}$ \\
1024 & 51688 & $\mathrm{~B}$ & UT $^{\mathrm{a}}$ & 0.88 & $\mathrm{H}$ \\
J.N & 51693 & $\mathrm{~B}$ & UT $^{\mathrm{a}}$ & 0.86 & $\mathrm{H}$ \\
& & & & & \\
\hline
\end{tabular}

* Strain number of the Research Center for Pathogenic Fungi and Microbial Toxicoses, Chiba University; a = Untypable mating type

USA). In addition, their phenoloxidase activity (melanin production) was tested with the DOPA agar medium ${ }^{4}$.

All of the strains were maintained on Sabouraud glucose agar slants. C. neoformans strains giving blue color in canavanine-glycinebromothymol blue test ${ }^{13}$ were judged as var. gattii. Those showing yellow color were judged as variety group of var. neoformans and var. grubii. The group was further subdivided by serotypes into two varieties. Those with serotype D was judged as var. neoformans. Those with serotype A was judged as var. grubii.

Serotyping: The slide agglutination tests with 6 factor sera ${ }^{9}$ were 


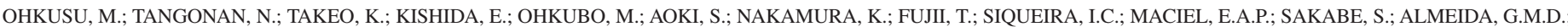
HEINS-VACCARI, E.M. \& LACAZ, C.S. - Serotype, mating type and ploidy of Cryptococcus neoformans strains isolated from patients in Brazil. Rev. Inst. Med. trop. S. Paulo, 44(6): 299-302, 2002.

performed using the Crypto Check Kit (Iatron Laboratories) as previously described by TAKEO et al., $1993^{24}$.

Mating tests: The method was essentially the same as described in KWON-CHUNG \& BENNETT $(1978)^{10}$. The strains IFM 5844 (= NIH B-3501) and IFM 5845 (= NIH B-3502) of Filobasidiella neoformans var. neoformans were used as the tester strain $\alpha$ and $a$, respectively. Small amount of yeast cells on a loop from 1-2, day-old cultures on potato dextrose agar slant at $25^{\circ} \mathrm{C}$ was mixed with similar amount of cells of the $\alpha$ or $\alpha$ tester strain in distilled water and incubated for 7 weeks on hay cube agar at $25^{\circ} \mathrm{C}$. To check homothalism of each strain, the above incubation was also done without mixing the tester strains. The existence of filamentous cells with clamp connections, basidia, and basidiospores was checked at one week interval until 7 weeks under a stereoscope Nikon SZ-PT, or a light microscope Olympus BS2. Only those strains having the above set of the sexual structures were judged as positive.

Analysis of cellular DNA: The methods were used as described previously by TAKEO et al., 1995 $5^{23}$. Briefly, cellular DNA was stained quantitatively with $5 \mu \mathrm{g} \mathrm{ml}^{-1}$ propidium iodide and RNA was digested using $0.5 \mathrm{mg} \mathrm{ml}^{-1}$ RNase from bovine pancreas (Sigma type 1-AS). Then, DNA content was examined in each cell with regard to cell morphology using a laser-scanning-cytometer Olympus model LSC 101 or a fluorescence microscope Olympus model BS2 equipped with a photomultiplier ${ }^{19}$.

\section{RESULTS}

Strains isolated from AIDS patients: Among a total of 61 strains isolated from AIDS patients, 60 strains did not grow efficiently and did not change the light green color of the agar medium to cobalt blue when inoculated onto CGB agar medium. These strains should belong to either var. neoformans or var. grubii.

The results of serotyping, mating type determination and ploidy assay of a total of 61 strains are shown in Table 1. Among the 61 strains, all except one were serotyped as A. One strain was serotype B. No strains possessed serotype C, D or AD. Thus, strains isolated from AIDS patients were essentially var. grubii.

The sexual characteristics of the isolates were determined according to the emergence of hyphae with clamp connections, basidia and basidiospores when mated with the $a$ and $\alpha$ tester strains in a sporulation medium. Among the 61 strains tested, 58 (94\%) were of the heterothallic MAT $\alpha$ type and 3 gave no distinctive sexual responses. Neither the heterothallic MAT $a$ type nor homothallic MAT $a / \alpha$ type were found. Fifty four $(90 \%)$ of the 58 MAT $\alpha$ strains were haploid and 4 were diploid. All the 3 asexual strains (two serotype A and one serotype B) were haploid.

Morphologically, it was also noted that the cells and nuclei of the haploid strains were similarly small in size. On the contrary, the cellular and nuclear sizes of the diploid strains were distinctly larger than those of the haploid strains. Neither triploid nor tetraploid strains were observed.

Strains isolated from non-AIDS patients: Fifteen strains were found to be var. grubii (serotype A). These were all MAT $\alpha$ and haploid. Eight var. gattii strains were all serotype B. Consistent with the results of color development in the CGB test, none of the strains from var. gattii were of the A, D or AD serotypes. As to mating type, these did not respond well to both of the tester strains. They were all haploid.

\section{DISCUSSION}

The different geographical distribution of the three varieties of $C$. neoformans have aroused attention to a possible relationship between varieties of causative strains and countries. Interestingly, a number of epidemiological studies have demonstrated that almost all cryptococcal infections in AIDS patients are due to var. neoformans or var. grubii (serotype A or D) strains, even in the var. gattii-epidemic areas ${ }^{2,10,11,15,20}$. Concerning $C$. neoformans strains isolated from cryptococcosis patients in Brazil, var. neoformans (serotypes A, actually C. grubii) and var. gattii (serotype B) were the common causative agents of cryptococcosis and the number of cases increased after the advent of $\operatorname{AIDS}^{2,14,21,22}$. As clearly shown in Tables 1 and 2, our results support the above observations, and furthermore demonstrate that serotype A is predominant in the C. neoformans isolates from AIDS patients in São Paulo and surrounding areas.

The mating types of $C$. neoformans isolates are important for understanding their ecology and virulence. The $\alpha$-mating type strains are much more prevalent than $\alpha$-mating type strains in environmental and clinical isolates. MAT $\alpha$ strains have been shown to develop extensive hyphae, without mating, and to produce viable basidiospores under appropriate conditions. This ability, found only in the MAT $\alpha$ strains, explains the mating type ratios in environmental and clinical isolates ${ }^{1}$. There were no $a$-mating type strains among the 84 strains examined in the present study. In our study, 2 of the 84 isolates were asexual. In the literature, the incidence of asexual (untypable) strains was about $10 \%$, except for var. gattii strains. Var. gattii strains are notorious for difficulty in obtaining the sexual stages ${ }^{7}$. Here 8 gattii strains were obtained from 8 non-AIDS patients, all of them did not show mating ability, although they were all haploid. Self-fertile MAT $a / \alpha$ strains were not found in our 84 isolates. KWON-CHUNG et al. reported that the MAT $\alpha$ type was more virulent than the opposite $a$-mating type $\mathrm{e}^{10,12}$. The predominance of the MAT $\alpha$ strains observed in the present study is in accordance with their findings, since the strains examined were isolated from patients.

Strains, isolated from São Paulo and surrounding areas, were mostly haploid. This is in good agreement with the well known fact that most C. neoformans strains show mating ability as heterothallic MAT $\alpha$. We found no homothallic MATa/ $\alpha$ and asexual diploid strains, but 4 heterothallic MAT $\alpha$ diploid strains. As to ploidy determination with a large number of environmental and clinical isolates, there have been reported only on our two previous papers. The first paper deals with the strains isolated from non-AIDS patients and environment essentially in $\mathrm{Japan}^{24}$ and the other, from AIDS patients in Thailand ${ }^{8}$. Thus, the strains examined in this and in the former two papers were isolated from three different geographical regions. However, heterothallic MAT $\alpha$ diploid strains are consistently found at relatively high incidence of more than $5 \%$. Thus, the existence of heterothallic MAT $\alpha$ diploid strains can be regarded as a cellular characteristic of $C$. neoformans.

\section{RESUMO}

Sorotipos, "mating type" e ploidia de amostras de $C$. neoformans isoladas de pacientes no Brasil

Foram estudados os sorotipos, "mating type" e ploidia de 84 amostras 


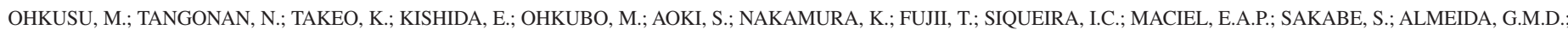
HEINS-VACCARI, E.M. \& LACAZ, C.S. - Serotype, mating type and ploidy of Cryptococcus neoformans strains isolated from patients in Brazil. Rev. Inst. Med. trop. S. Paulo, 44(6): 299-302, 2002.

de C. neoformans isoladas de 61 pacientes com AIDS e 23 não-AIDS em São Paulo. Das amostras isoladas de pacientes com AIDS, 60 foram identificadas como var. grubii (sorotipo A) e 1 como var. gattii (sorotipo B). Não houve isolamento do sorotipo D. Entre as amostras isoladas, de pacientes não-AIDS, 15 foram de var. grubii (sorotipo A) e as 8 restantes de var. gattii, todos do sorotipo B. Setenta e três dos 75 sorotipos A foram identificadas como cepas heterotálicas do fenótipo $\alpha$ (MAT $\alpha)$ e as 2 remanescentes não-tipáveis (assexuada), eram haplóides. A maioria das cepas MATo (69/73) era haplóide sendo 4 diplóide. Não houve o isolamento de fenótipo $a$ (MAT $a$ ) entre as 84 cepas analisadas. Todas as 11 amostras de var. gattii eram do sorotipo B e haplóides. Não foram observados os sorotipos $\mathrm{AD}$ e $\mathrm{C}$, nem células triplóides ou tetraplóides entre as 84 amostras estudadas. Os resultados sugerem, que as características sorológicas, sexuais e de ploidia de $C$. neoformans, isoladas de pacientes com AIDS em São Paulo, são particularmente simples, a maioria do sorotipo A, enquanto que nos pacientes não-AIDS foram observados tanto os sorotipos A quanto o B.

\section{ACKNOWLEDGEMENTS}

We thank Marcello Franco, Department of Pathology, UNIFESP, for discussion and encouragement. This study was performed as the program "Frontier Studies and International Networking of Genetic Resources in Pathogenic Fungi and Actinomycetes (FN-GRPF)" through the Special Coordination Funds for Promoting Science and Technology from the Ministry of Education, Culture, Sports, Science and Technology, the Japanese Government in 2001.

Fundação de Amparo à Pesquisa do Estado de São Paulo. (FAPESP00/09372-8).

\section{REFERENCES}

1. ALSPAUGH, J.A.; PERFECT, J.R. \& HEITMAN, J. - Signal transduction pathways regulating differentiation and pathogenicity of Cryptococcus neoformans. Fungal Genet. Biol., 25: 1-14, 1998.

2. BARRETO DE OLIVEIRA, M.T. - Serotypes, killer biotypes, genetic diversity and mating-type of Cryptococcus neoformans strains isolated from patients and environmental sources in Brazil. São Paulo, 2001. (Tese de Doutorado - Instituto de Ciências Biomédicas da Universidade de São Paulo).

3. CASADEVALL, A. \& PERFECT, J.R. - Ecology of Cryptococcus neoformans. In: CASADEVALL, A. \& PERFECT, J.R., ed. Cryptococcus neoformans. Washington, ASM Press, 1998. p. 41-70.

4. CHASKES, S. \& TYNDALL, R.L. - Pigment production by Cryptococcus neoformans from para- and ortho-Diphenols: effect of the nitrogen source. J. clin. Microbiol., 1: 509-514, 1975

5. FELL, J.W. \& STATZELL-TALLMAN, A. - Cryptococcus Vuillemin. In: KURTZMAN, C.P. \& FELL, J.W. The yeasts, a taxonomic study. 4. ed. Amsterdam, Elsevier, 1998. p. 762.

6. FRANZOT, S.P.; SALKIN, I.F. \& CASADEVALL, A. - Cryptococcus neoformans var. grubii separate varietal status for Cryptococcus neoformans serotype A isolates. J. clin. Microbiol., 37: 838-840, 1999.

7. HALLIDAY, C.L.; BUI, T.; KROCKENBERGER, M. et al. - Presence of $\alpha$ and $a$ mating types in environmental and clinical collections of Cryptococcus neoformans var. gattii strains from Australia. J. clin. Microbiol., 37: 2920-2926, 1999.
8. ITO-KUWA, S.; PIENTHAWEECHAI, K.; AOKI, S. et al. - Serotype, mating type and ploidy of Cryptococcus neoformans strains isolated from AIDS patients in Thailand. J. Mycol. méd., 10: 191-196, 2000.

9. KABASAWA, K.; ITAGAKI, H.; IKEDA, R. et al. - Evaluation of a new method for identification of Cryptococcus neoformans which uses serologic tests aided by selected biological tests. J. clin. Microbiol, 29: 2873-2876, 1991.

10. KWON-CHUNG, K.J. \& BENNETT, J.E. - Distribution of $\alpha$ and $a$ mating types of Cryptococcus neoformans among natural and clinical isolates. Amer. J. Epidem., 108: 337-340, 1978.

11. KWON-CHUNG, K.J. \& BENNETT, J.E. - Epidemiologic differences between the two varieties of C. neoformans. Amer. J. Epidem., 120: 123-130, 1984.

12. KWON-CHUNG, K.J.; EDMAN, J.C. \& WICKES, B.L. - Genetic association of mating types and virulence in Cryptococcus neoformans. Infect. Immun., 60: 602-605, 1992.

13. KWON-CHUNG, K.J.; POLACHECK, I. \& BENNETT, J.E. - Improved diagnostic medium for separation of Cryptococcus neoformans var. neoformans (serotypes A and D) and Cryptococcus neoformans var. gattii (serotypes B and C). J. clin. Microbiol., 15: 535-537, 1982.

14. LACAZ, C. da S. \& RODRIGUES, M.C. - Sorotipagem do Cryptococcus neoformans. Rev. bras. Med., 40: 297-300, 1983

15. LAZERA, M.S.; CAVALCANTI, M.A.S.; TRILLES, L.; NISHIKAWA, M.M. \& WANKE, B. - Cryptococcus neoformans var. gattii - evidence for a natural habitat related to decaying wood in pottery tree hollow. Med. Mycol., 36: 119-122, 1998.

16. LENGELER, K.B.; COX, G.M. \& HEITMAN, J. - Serotype AD strains of Cryptococcus neoformans are diploid or aneuploid and are heterozygous at the mating-type locus. Infect. Immun., 69: 115-122, 2001.

17. MITCHEL, T.G. \& PERFECT, J.R. - Cryptococcosis in the era of AIDS - 100 years after the discovery of Cryptococcus neoformans. Clin. Microbiol. Rev., 8: 515-548, 1995.

18. MONTENEGRO, H. \& PAULA, C.R. - Environmental isolation of Cryptococcus neoformans var. gattii and C. neoformans var. neoformans in the city of São Paulo, Brazil. Med. Mycol., 38: 385-390, 2000.

19. OHKUSU, M.; HATA, K. \& TAKEO, K. - Bud emergence is gradually delayed from S to $\mathrm{G}_{2}$ with progression of growth phase in Cryptococcus neoformans. FEMS Microbiol. Lett., 194: 251-255, 2001.

20. ROZENBAUM, R.; GONÇALVES, A.J.; WANKE, B. \& VIEIRA, W. - Cryptococcus neoformans var. gattii in a Brazilian AIDS patient. Mycopathologia (Den Haag), 112: $33-34,1990$.

21. ROZENBAUM, R.; GONÇALVES, A.J.; WANKE, B. et al. - Cryptococcus neoformans varieties as agents of cryptococcosis in Brazil. Mycopathologia (Den Haag), 119: 133-136, 1992.

22. SEVERO, L.C.; DE MATTOS OLIVEIRA, F. \& LONDERO, T. - Cryptococcosis due to Cryptococcus neoformans var. gattii in Brazilian patients with AIDS. Report of three cases. Rev. iberoamer. Micol., 16: 152-154, 1999.

23. TAKEO, K.; TANAKA, R.; MIYAJI, M. \& NISHIMURA, K. - Unbudded G2 as well as G1 arrest in the stationary phase of the basidiomycetous yeast Cryptococcus neoformans. FEMS Microbiol. Lett., 129: 231-235, 1995.

24. TAKEO, K.; TANAKA, R.; TAGUCHI, H. \& NISHIMURA, K. - Analysis of ploidy and sexual characteristics of natural isolates of Cryptococcus neoformans. Canad. J. Microbiol., 39: 958-963, 1993.

Received: 19 July 2002

Accepted: 23 September 2002 